\title{
CAUSE, EFFECT AND MINIMIZING METHOD OF CONSTRUCTION PROJECTS DELAYS IN OUTSKIRT AREAS AFGHANISTAN
}

\section{HEKMATULLAH RAHIMI ${ }^{1}$ \& GAGANDEEP ${ }^{2}$}

${ }^{I}$ Research Scholar, Construction Technology Management, Chandigarh University, India

${ }^{2}$ Assistant Professor, Department of Civil Engineering, Chandigarh University, India

ABSTRACT
A project completed with its allocated time and budget said to be successful project but mostly projects complete less or
beyond pre-scheduled time and budget due to some different factors around the world both in developed and developing
countries with different percentage variance from its predetermined time, so that research conducted to study cause,
effect and minimizing methods of construction project delays in outskirt areas of Afghanistan. A questionnaire survey
and face to face interview carried out. After analysis of this survey, eight main causes of delay and seven effects of
delay with five main minimizing methods were identified. Top eight causes are (1) Security challenge during
implementation of project (2) Corruption (3) Low-quality materials (4) Lack of technology mechanical equipment (5)
insufficient data collection and survey before design by consultant (6) Delay in progress payment by owner (7) Slowness
in decision-making process by owner (8) ineffective and poor scheduling of project by contractor. Seven effects of delay
are (1) time overrun (2) Dispute (3) Cost overrun (4) Arbitration (5) Litigation (6) total abandonment, (7)
disappointment of foreign donors. Top five minimizing methods are (1) preparing of a secured environment for project
operation (2) Hiring of experienced manager, (3) effective strategic planning (4) use up-date technology utilization (5)
site management supervision.
KEYWORDS: Effect And Minimizing Method Of Construction Projects

Received: Jun 05, 2020; Accepted: Jun 25, 2020; Published: Jul 05, 2020; Paper Id.: IJMPERDJUN2020221

\section{INTRODUCTION}

Delays in the construction industry are a worldwide phenomenon, a delay of construction projects is one of a major challenge during the implementation of construction projects. It is the late completion of activities of projects compared to preplanned estimating time. Afghanistan achieved development in the construction industry during the last two decades in proportion to previous decades. Private sectors played the highest role compared to other sectors. With the decision of the US and NATOs to extend its mission in Afghanistan beyond 2016, the construction industry will experience more promotion. As construction materials are imported from other countries, there is an opportunity for investors to produce construction material inside the country. other than government expenditure on development projects, there is a huge demand for houses in the capital and provinces, in 2014-15, 729 building was constructed valued $\$ 169.6$ million and another 523 buildings were under construction and the construction sector contributed 7-10\% to GDP in recent years according to Ministry of Commerce and Industries. On the other hand, the Government of Afghanistan is not succeeded in building huge projects, for example, Sharake Jadid construction projects which will provide residency for three million persons. Master plan of this project was prepared with help of French, German and Afghan engineers which cast \$60 million in 2008 and every unit of residency will cast 1000 thousand dollars, about 10 Ministry and governmental organization made association 
named Adara Mostaqa Kabul Jadid, this administration is responsible to work on this projects but there is no sign of any development of this project. delay of construction projects affect negatively the prestige of Afghan government which create distance between people and government organization, it shows incapacity of government. [1] studied the causes and effects of delay in the Malaysian construction industry. Ten critical causes were identified in the research. these are (1) improper planning by contractor, (2) poor site management by contractors, (3) inadequate experience of contractors, (4) inadequate client payment to completed work, (5) problems with subcontractors, (6) material shortage, (7) labor supply, (8) failure and availability of equipment, (9) lack of communication between parties and (10) mistakes during construction stage. Six main effects are (1) time overrun, (2) cost overrun, (3) disputes, (4) arbitration, (5) litigation, (6) total abandonment.[2] conducted research to study construction delays in client perception. 12 main factors of delays out of 18 factors were identified. 12 factors are mistake and inconsistencies in the design documentation, changes in the project under implementation, investor delay in payment to contractor, investor's difficulties in gaining funds to finance the investment, untrained labor hiring, adverse weather conditions, delays in the supply materials, poor quality of the management and supervision, infective planning including the development of schedules, unforeseen changes in the existing law, contractors lack of access to modern technologies, insufficient necessary equipment at the construction site. In Saudi Arabia, [3] conducted research, study shows that only $30 \%$ of construction projects were carried out within preschedule dates and average time overrun was between $10 \%$ to 30\% [4] studied delay of construction projects in India. Factor analysis and regression modeling were used to determine the importance of delay factors. From factor analysis most critical factors of delays were recognized as (1) lack of commitment, (2) inefficient site management, (3) poor site coordination, (5) lack of clarity in project scope, (6) lack of communication and (7) substandard contracts. [5] studied the delay of a project under the Build Operate Transfer Model. The outcomes analyzed using traditional statistical and structural equation modeling methods and it was identified that negotiation and signing of the agreement is the most significant stage in construction projects in which uncertainty on political issues and government-finished items, improper contract planning, debt problems are the highest rank causes of delays. [6]studies the ranking of delay factors in construction projects after the Egyptian revolution. The top important causes of delays were delay in progress payments, bribes, shortage of equipment, ineffective planning of projects, errors and rework, poor management and overseeing in a site, inappropriate contractors, sudden failures, contractor's inadequate experience, incompetent project time, equipment breakdowns, change orders. [7] studied the time delay and cost overrun in Qatari Public construction projects. Project delay factors were classified into three major groups in this research. (1) excusable (2) concurrent (3) nonexcusable.[8] studied delays in construction projects in Jordan. A survey was carried out and most respondents agreed that orders change by owner and contractor's financial problems are the leading causes and weather condition and government law changes are less ranked causes. [9] studies causal factors of delay in the Nuclear Power Plant Project. Thirteen major causes were identified. Missing schedule update, design error, scope change, a late proposal from a contractor, vendor materials do not meet specification, funding, schedule productivity, resource productivity, rework, owner decision, weather, plant support engineering. [10] studied causes of delay in Saudi public construction projects and ranked factors under four groups factors during awarding of tenders, general factors, factors after awarding, factors before awarding of the tender. [11] studied the effects of organizational culture on delay in construction. The finding of the study indicates that the US located companies mostly based on "clan" culture, where the company gives great significance to teamwork, participation, and consensus. Indian companies dominated by market culture. The study also indicates that the percentage of delay is lower in the US compared to India. [12] studied cost escalation and schedule in road construction projects in Zambia. The main causes of delay were delay payments, financial problems of both contractors and clients, poor supervision, poor 
coordination, changes in drawings, staffing problems, equipment unavailability, material procurement, labor disputes. [13] studied cost overrun and delays in energy megaprojects in Brazil. The finding shows that construction cost was on average, $97.53 \%$ above the initial estimates and $74.28 \%$ increase in completion of construction. In this research, focus concentrated on causes, effects of delays with its minimizing methods in outskirt areas of Afghanistan.

\section{METHODOLOGY}

A questionnaire was prepared in four different sections to distinguish the comprehension of contractors, client, consultant and manager on the relative significance of causes and effects with its minimizing construction delay methods in the Afghanistan construction industry.

The questionnaire has four sections. The first section included background information about the respondents. The second section of the questionnaire included causes of construction delay which had 62 delay factors taken from the literature review and approved by university professors. These factors were classified into the following six major groups.

- Client/Owner related factors: delay in progress payment, delay to furnish and deliver the site, changes order by owner during construction, delay approving shop drawing and sample, poor communication and coordination, slowness in decision-making process, conflict between joint ownership, suspension of work by owner, death of owner, delay in change order by client.

- Contractor related factors: rework due to errors during construction delay in site, delay in site mobilization, poor qualification of contractors technical staff, slowness in decision process, conflict between ownership of project, delays in subcontractor work frequent change of subcontractors, ineffective and scheduling of project, poor communication, and coordination, conflict between contractor and other parties, improper construction methods implementation, death of contractor, shortage of technical professional in contractor organization safety rules and regulation not followed within contractors organization, incompetent technical staff assigned to the project, improper technical study by contractor during bidding stage, financial difficulties.

- Consultant related factors: delay in approaching major changes in the scope of work, poor communication, and coordination, inadequate experience of consultant, mistakes, and discrepancies in design, delay in producing design document, unclear and inadequate detail in drawing, insufficient data collection and survey before design, use of no advance engineering design software, slowness in giving instruction, poor inspection plan by consultant.

- Material related factors: a shortage of construction material in market, delay in material while they are needed, late procurement of materials, changes in materials types during construction, delay in the manufacturing special building materials, damage of sorted material while they are needed urgently, low quality of material, inappropriate/misuse of materials. Poor material handling on site.

- Equipment related factors: equipment breaks down, shortage of equipment, low level of equipment, lack of technology and mechanical equipment misuse of equipment.

- External factors: accident during, change in governmental law, corruption, delay performing final inspection and certification, delay in obtaining a permit from the municipality, weather effects on construction activities, security challenges during implementation of projects, the effect of subsurface and ground condition (soil, high water table).

The third section of the questionnaire includes effects of construction delay in construction industry taken from a 
literature review, these effects are Seven in number cost overrun, dispute, arbitration, time overrun, litigation, total abandonment, the disappointment of foreign donors.

The fourth section of the questionnaire focused on the methods how to minimize construction delay in the construction industry, factors included are frequent progress meeting, use update technology utilization, use proper and modern construction equipment, use appropriate construction method. Proper material procurement, accurate initial cost estimates, effective strategic planning, hiring of experienced manager, preparing of secured environment for project operation, clear information and communication channels, coordination between the parties involved, proper emphasis on past experience, complete and proper design at right time, site management and supervision, collaborative working in construction, compressing construction duration. At the end of the questionnaire, the respondents were asked to have a recommendation on the cause, effect and minimizing methods of delay. A five-point Likert Scale from 1 not significant to 5 extremely significant was adopted to gain the significance of respondents about causes, effects and minimizing methods of delays. The sampling method used in this research was the Snowball sampling method comes under the non-probability sampling techniques category. This method made ease to gain responses from professional respondents from a public and private organization, with the help of friends which saved time and money. 91 sets of questionnaires were prepared for data collection 40 sets of questionnaires were answered by respondents in face to face interview and 51 sets were sent via email. From 51 sets, we received only 32 sets of responses distributed to professional respondents in the construction field.

\subsection{Data Analysis}

Respondents Demographic are Given in Table 1.

Table 1: Respondents Demographic

\begin{tabular}{|l|c|c|}
\hline \multicolumn{1}{|c|}{ Age } & Frequency & Percent \\
\hline 2025 & 3 & 4.3 \\
\hline 2530 & 18 & 25.4 \\
\hline 3045 & 33 & 46.5 \\
\hline 4550 & 12 & 16.9 \\
\hline above 50 Education \\
\hline \multicolumn{2}{|c|}{ Designation } \\
\hline Graduate & 41 & 7 \\
\hline post graduate & 31 & 56.94 \\
\hline \multicolumn{2}{|c|}{ Experience } & 43.05 \\
\hline Manager & 16 & 27.8 \\
\hline Engineer / consultant & 19 & 22.2 \\
\hline Contractor & 17 & 26.4 \\
\hline client/owner & 37 & 23.6 \\
\hline \multicolumn{2}{|c|}{16} & 22.2 \\
\hline 15 years & 14 & 51.4 \\
\hline 610 years & 5 & 19.4 \\
\hline 1115 years & 19 & 6.9 \\
\hline more than 15 years & 8 & 26.4 \\
\hline Types of Projects Experienced Delays & 11.1 \\
\hline School & 25 & 34.7 \\
\hline Hospital & 20 & 27.8 \\
\hline public facilities & & \\
\hline housing estate & 16 & \\
\hline
\end{tabular}

\subsection{Calculation of Relative Importance of Factors}


The collected data was analyzed based on clients, contractors, consultants and managers point of view and Relative Importance Index RII $=\frac{\sum W}{A * N}$ where $\mathrm{W}$ is the weighting given to every factor by respondents (ranging from 1 to 5 ) $\mathrm{A}$ is the highest weight ( 5 in this case) and $\mathrm{N}$ is the total number of respondents. Relative Importance Index was analysis with help of Excel and SPSS for every cause of delays and 6 most significant causes are listed in table 2. Based on the RII of causes most of the disputes occurred in the Afghan construction industry are due to the client, contractor and external factors. The three most common causes between parties are poor communication and coordination of contractor, suspension of work with delays in progress payment by owner and corruption in governmental organizations. Client blames contractor for poor communication and coordination that cannot perform projects work as per client demand, these disrupted projects work. The contractor blames the client for suspension of projects work and delayed payment for completed work. corruption in the governmental organization is also an extremely big issue causing a delay in the inspection of projects' works finally causing projects to take longer time than pre-planned duration.

Table 2: Ranking of Six Most Significant Causes of Delays Based on Point of View of Owners, Contractors, Managers and Consultants

\begin{tabular}{|c|c|c|c|c|c|c|c|}
\hline \multirow[t]{2}{*}{ Client Point of View } & \multicolumn{5}{|c|}{$\begin{array}{l}\text { Percentage of Respondents } \\
\text { Scoring }\end{array}$} & \multirow[t]{2}{*}{ Rii } & \multirow[t]{2}{*}{ Rank } \\
\hline & 5 & 4 & 3 & 2 & 1 & & \\
\hline contractor related factors [rework due to errors during construction] & 11.8 & 35.3 & 52.9 & 0.0 & 0.0 & 0.72 & 4 \\
\hline contractor related factors [delays in site mobilization] & 17.6 & 52.9 & 23.5 & 0.0 & 5.9 & 0.74 & 2 \\
\hline $\begin{array}{l}\text { contractor related factors [poor qualification of contractors technical } \\
\text { staff] }\end{array}$ & 29.4 & 35.3 & 23.5 & 11.8 & 0.0 & 0.72 & 4 \\
\hline contractor related factors [ineffective and scheduling of project ] & 17.6 & 47.1 & 29.4 & 5.9 & 0.0 & 0.73 & 3 \\
\hline contractor related factors [poor communication and coordination] & 29.4 & 17.6 & 52.9 & 0.0 & 0.0 & 0.75 & 1 \\
\hline $\begin{array}{l}\text { External Factors [security challenge during the implementation of } \\
\text { projects] }\end{array}$ & 23.5 & 35.3 & 23.5 & 17.6 & 0.0 & 0.66 & 6 \\
\hline Contractor Point of View & 5 & 4 & 3 & 2 & 1 & RII & Rank \\
\hline owner related [delay in progress payment ] & 15.8 & 68.4 & 15.8 & 0.0 & 0.0 & 0.80 & 2 \\
\hline owner related [delay in change order by client ] & 26.3 & 36.8 & 36.8 & 0.0 & 0.0 & 0.78 & 3 \\
\hline owner related [suspension of work by owner] & 31.6 & 42.1 & 26.3 & 0.0 & 0.0 & 0.81 & 1 \\
\hline External Factors [corruption] & 31.6 & 31.6 & 26.3 & 5.3 & 5.3 & 0.76 & 5 \\
\hline $\begin{array}{l}\text { External Factors [security challenge during the implementation of } \\
\text { projects] }\end{array}$ & 36.8 & 36.8 & 10.5 & 5.3 & 10.5 & 0.77 & 4 \\
\hline material related [low quality of material ] & 31.6 & 26.3 & 31.6 & 5.3 & 5.3 & 0.75 & 6 \\
\hline Engineer / Consultant Point of View & 5 & 4 & 3 & 2 & 1 & RII & Rank \\
\hline owner related [slowness in decision making process] & 12.5 & 56.3 & 18.8 & 0.0 & 12.5 & 0.71 & 1 \\
\hline contractor related factors [ineffective and scheduling of project ] & 18.8 & 18.8 & 43.8 & 6.3 & 12.5 & 0.65 & 5 \\
\hline Equipment related [shortage of equipment ] & 12.5 & 25.0 & 31.3 & 31.3 & 0.0 & 0.64 & 6 \\
\hline External Factors [corruption] & 25.0 & 31.3 & 18.8 & 25.0 & 0.0 & 0.71 & 1 \\
\hline material related [low quality of material ] & 12.5 & 43.8 & 12.5 & 25.0 & 6.3 & 0.66 & 4 \\
\hline material related [poor material handling on site] & 25.0 & 25.0 & 18.8 & 25.0 & 6.3 & 0.68 & 3 \\
\hline Manager Point of View & 5 & 4 & 3 & 2 & 1 & RII & Rank \\
\hline $\begin{array}{l}\text { consultant related [insufficient data collection and survey before } \\
\text { design] }\end{array}$ & 25 & 40 & 25 & 10 & 0 & 0.76 & 3 \\
\hline Equipment related [lack of technology mechanical equipment ] & 35 & 35 & 30 & 0 & 0 & 0.81 & 2 \\
\hline External Factors [corruption] & 30 & 35 & 25 & 0 & 10 & 0.75 & 5 \\
\hline $\begin{array}{l}\text { External Factors [security challenge during the implementation of } \\
\text { projects] }\end{array}$ & 40 & 50 & 5 & 0 & 5 & 0.84 & 1 \\
\hline consultant related [slowness in giving instruction ] & 25 & 35 & 35 & 5 & 0 & 0.76 & 3 \\
\hline material related [low quality of material ] & 20 & 45 & 25 & 10 & 0 & 0.75 & 5 \\
\hline
\end{tabular}

Table 3: Ranking and RII of Critical Causes Based on Point of Veiw of All \begin{tabular}{|l|l} 
Over All Point of View & Percentage of Respondent Scoring
\end{tabular} RII $\quad$ Rank 


\begin{tabular}{|l|c|c|c|c|c|c|c|}
\hline & $\mathbf{5}$ & $\mathbf{4}$ & $\mathbf{3}$ & $\mathbf{2}$ & $\mathbf{1}$ & $\mathbf{1}$ & \\
\hline owner related [delay in progress payment ] & 12.5 & 40.3 & 22.2 & 22.2 & 2.8 & 0.675 & 6 \\
\hline owner related [slowness in decision making process] & 8.3 & 47.2 & 19.4 & 18.1 & 6.9 & 0.664 & 7 \\
\hline $\begin{array}{l}\text { contractor related factors [ineffective and scheduling of } \\
\text { project ] }\end{array}$ & 12.5 & 30.6 & 34.7 & 12.5 & 9.7 & 0.647 & 11 \\
\hline consultant related [slowness in giving instruction ] & 11.1 & 30.6 & 36.1 & 16.7 & 5.6 & 0.650 & 10 \\
\hline $\begin{array}{l}\text { consultant related [insufficient data collection and survey } \\
\text { before design] }\end{array}$ & 16.7 & 34.7 & 30.6 & 9.7 & 8.3 & 0.683 & 5 \\
\hline material related [low quality of material ] & 22.2 & 36.1 & 23.6 & 13.9 & 4.2 & 0.717 & 3 \\
\hline material related [poor material handling on site] & 12.5 & 27.8 & 41.7 & 13.9 & 4.2 & 0.661 & 9 \\
\hline Equipment related [shortage of equipment ] & 6.9 & 43.1 & 29.2 & 16.7 & 4.2 & 0.664 & 7 \\
\hline $\begin{array}{l}\text { Equipment related [lack of technology mechanical } \\
\text { equipment ] }\end{array}$ & 19.4 & 34.7 & 29.2 & 11.1 & 5.6 & 0.703 & 4 \\
\hline External Factors [corruption] & 29.2 & 29.2 & 25.0 & 12.5 & 4.2 & 0.733 & 2 \\
\hline $\begin{array}{l}\text { External Factors [security challenge during the } \\
\text { implementation of projects] }\end{array}$ & 31.9 & 33.3 & 18.1 & 8.3 & 8.3 & 0.744 & 1 \\
\hline
\end{tabular}

Table 4: Spearman's Rank Correlation Coefficients of the Ranking of Clients, Consultants and Contractors Forcauses of Delay (11)

\begin{tabular}{|c|c|c|c|c|c|c|}
\hline \multicolumn{3}{|c|}{ Spearman's Rho } & Client & Contractor & Consultant & Manager \\
\hline \multirow{12}{*}{ Spearman's rho } & \multirow{3}{*}{ Client } & Correlation Coefficient & 1.000 & -.347 & -.279 & .131 \\
\hline & & Sig. (1-tailed) & & .134 & .190 & .343 \\
\hline & & $\mathrm{N}$ & 12 & 12 & 12 & 12 \\
\hline & \multirow{3}{*}{ Contractor } & Correlation Coefficient & -.347 & 1.000 & .214 & $.507^{*}$ \\
\hline & & Sig. (1-tailed) & .134 & & .252 & .046 \\
\hline & & $\mathrm{N}$ & 12 & 12 & 12 & 12 \\
\hline & \multirow{3}{*}{ Consultant } & Correlation Coefficient & -.279 & .214 & 1.000 & -.319 \\
\hline & & Sig. (1-tailed) & .190 & .252 & & .156 \\
\hline & & $\mathrm{N}$ & 12 & 12 & 12 & 12 \\
\hline & \multirow{3}{*}{ Manager } & Correlation Coefficient & .131 & $.507^{*}$ & -.319 & 1.000 \\
\hline & & Sig. (1-tailed) & .343 & .046 & .156 & \\
\hline & & $\mathrm{N}$ & 12 & 12 & 12 & 12 \\
\hline
\end{tabular}

Correlation is significant at the 0.05 level (1-tailed).

Table 5: Ranking And Relative Impotence Index of Effects of Delay

\begin{tabular}{|l|c|c|c|c|c|c|c|}
\hline \multicolumn{1}{|c|}{ Effects } & $\mathbf{5}$ & $\mathbf{4}$ & $\mathbf{3}$ & $\mathbf{2}$ & $\mathbf{1}$ & RII & Rank \\
\hline Cost overrun & 4.2 & 33.3 & 40.3 & 16.7 & 5.6 & 0.63 & 4 \\
\hline Dispute & 15.3 & 43.1 & 19.4 & 15.3 & 6.9 & 0.69 & 2 \\
\hline Time overrun & 29.2 & 38.9 & 19.4 & 9.7 & 2.8 & 0.76 & 1 \\
\hline Arbitration & 4.2 & 26.4 & 30.6 & 37.5 & 1.4 & 0.59 & 5 \\
\hline total abandonment & 4.2 & 15.3 & 25.0 & 47.2 & 8.3 & 0.52 & 7 \\
\hline Litigation & 5.6 & 36.1 & 36.1 & 19.4 & 2.8 & 0.64 & 3 \\
\hline disappointment of foreign donors & 8.3 & 19.4 & 30.6 & 27.8 & 13.9 & 0.56 & 6 \\
\hline
\end{tabular}

Table 6: Minimizing Methods of Constrcution Project Delay

\begin{tabular}{|l|c|c|c|c|c|c|c|}
\hline \multicolumn{1}{|c|}{ Minimizing Methods } & $\mathbf{5}$ & $\mathbf{4}$ & $\mathbf{3}$ & $\mathbf{2}$ & $\mathbf{1}$ & RII & Rank \\
\hline frequent progress meeting & 8.3 & 40.3 & 34.7 & 12.5 & 4.2 & 0.67 & 7 \\
\hline use up-date technology utilization & 18.1 & 34.7 & 33.3 & 12.5 & 1.4 & 0.71 & 4 \\
\hline use proper and modern construction equipment & 11.1 & 37.5 & 26.4 & 19.4 & 5.6 & 0.66 & 8 \\
\hline use of appropriate construction methods & 6.9 & 25.0 & 36.1 & 27.8 & 4.2 & 0.61 & 11 \\
\hline accurate initial cost estimates & 8.3 & 30.6 & 43.1 & 15.3 & 2.8 & 0.65 & 9 \\
\hline effective strategic planning & 16.7 & 44.4 & 27.8 & 9.7 & 1.4 & 0.73 & 3 \\
\hline Hiring of experience manager & 30.6 & 36.1 & 22.2 & 5.6 & 5.6 & 0.76 & 2 \\
\hline preparing of secured environment for project operation & 38.9 & 20.8 & 25.0 & 13.9 & 1.4 & 0.76 & 1 \\
\hline frequent coordination between the parties involved & 8.3 & 36.1 & 36.1 & 12.5 & 6.9 & 0.65 & 9 \\
\hline
\end{tabular}




\begin{tabular}{|l|c|c|c|c|c|c|c|}
\hline complete and proper design at the right time & 9.7 & 20.8 & 36.1 & 27.8 & 5.6 & 0.60 & 12 \\
\hline site management and supervision & 16.7 & 25.0 & 45.8 & 11.1 & 1.4 & 0.69 & 5 \\
\hline collaborative working in construction & 8.3 & 41.7 & 31.9 & 15.3 & 2.8 & 0.68 & 6 \\
\hline
\end{tabular}

\section{DISCUSSIONS OF RESULTS}

Factors deduced from data analysis are illustrated in this section, first causes of delays, second effects of delays third we remark the minimizing methods of delays.

Top seven most significant causes of delays based on all respondents overview as included in table 3 are (1) External Factor (security challenge during the implementation of projects) with RII $=0.744$ (2) External Factor (corruption) whit RII $=0.733$ (3) material related (low quality of material) with RII $=0.717$ (4) Equipment related (lack of technology mechanical equipment) with RII $=0.703$ (5) consultant related (insufficient data collection and survey before design) with RII $=0.683$ (6) owner related (delay in progress payment) with RII $=0.675$ (7) owner related (slowness in decision-making process) with RII $=0.664$

\subsection{Security Challenge During Implementation of Project:}

The Safe and security rank of Afghanistan is 166th out of 167 according to Legatum and Prosperity IndexTM. in accordance to this rank and survey was done in this research, insecurity critically challenges the projects to be performed within scheduled time and budget, despite, Afghan government with the US and NATOs member countries try hard to prepare welfare and secured environment.

\subsection{Corruption}

Afghanistan ranking in corruption is 177th out of 180 countries according to corruption perception INDEX 2017 reported by Transparency International under this rank and analyzed survey from respondents to research shows that Afghanistan governmental administration deepened in corruption. Corruption causes a development project to be delayed from its scheduled time.

\subsection{Low Quality Materials}

Afghanistan suffered four decades' war, this war has devastated development plans, industrializing plans, manufacturing plans and patriot people who were to extensively implement these plans. That is the reason today we import low-quality material from regional countries, besides this, there is no standard assessment agency to scan all materials. Low-quality materials imported and caused controversy in project completion

\subsection{Lack of Technology Mechanical Equipment}

Technology and mechanical equipment advancement improve collaboration and prevent the complexity of construction projects. It allows us to escalate productivity. With the help of technology, a taller, stronger and efficient structure can be built. Lack of technology will consume more time for the building of any special task in construction projects, in conclusion, it causes delays in projects

\subsection{Insufficient Data Collection and Survey Before Design}

Consultants designs project without study and collecting sufficient data due to some reasons, like insecurity or implementing of the same project in different regions with different climate and soil condition can face project to delays while constructing stage

\subsection{Delay in Progress Payment by Owner}


Construction projects require a huge amount of money for project works. Contractors most of the time face problems to keep continue projects work and sometimes projects delay due to late payment by the owner of projects

\subsection{Slowness in Decision Making Process by Owner}

The right decision at the right time drives forward projects to work into the completion point. in some cases, slowness in decision making by the owner side happens which causes a delay in the construction project.

\section{EFFECTS OF DELAYS}

While working in construction project any mistake due to inadequate planning, delay payment, and other reasons have impacts on project progress. Seven effects of delays for the construction project were ranked by respondents as shown in table 4.

4.1. Time Over Run: All respondents ranked time overrun as the effect of delay in the construction industry caused by contractor, consultant and external factors mostly. Mistakes from involved parties in project work increase project fulfillment time

4.2. Dispute: Contractor's improper planning, owner 's delay payments and poor communication between parties create disputes among involved parties.

4.3. Cost Overrun: Security challenges during implementation of the project, Corruption, low-quality materials, lack of technology mechanical equipment, Insufficient data collection and survey before design, delay in progress payment by owner are reasons to cost overrun of the project

4.4. Arbitration: Whenever, dispute occur between contractors and client of project. There is third party to arbitrate and settle the dispute between involved parties.

4.5. Litigation: Litigation is the last step to settle the risen disputes between parties (contractors, client, external related factors)

4.6. Total Abandonment: client related factors, contractor related factors and other factors make construction projects totally abandon.

4.7. Disappointment of Foreign Donors: Foreign donors work for health, education and human rights to support deprived people who are living in rural areas, so that, projects and programs which are supported by foreign donors face security challenges, corruption and other disputes in the region. It makes donors disappointed

\section{MINIMIZING METHODS TO MINIMIZE PROJECT DELAY:}

Minimizing methods which deduced from questionnaire analysis shown in table 5 are described in this section to prevent construction projects in outskirt areas of Afghanistan from delays.

5.1. Preparing of Secured Environment for Project Operation: Secured environment escalate working efficiency in construction project. This is achieved by government to prepare secured environment. Work force and authorized personal of projects work with confidence and dedication if the secured environment is available and project will not experience delays.

5.2. Hiring of Experience Manager: Experience manager in project creates blueprint that direct whole project from ideation 
to fruition, specifying project scope, resources, time frame, communication strategy between parties and minimize project from delays.

5.3. Effective Strategic Planning: Strategic planning is critically significant to definite the direction of your construction project. Well thought of strategic plan is focus on stakeholders and project team to ward objective and strategic planning assure efficient delivery of construction project with all standard within time.

5.4. Use Up-Date Technology Utilization: Many technologies, devices and popular software, BIM, mobile device, apps, laser scanning, drones and GPS tracking proven their effectiveness in building and infrastructure projects with 20 percent reduction in the total cost of a project as well as essential improvements in completion time, quality and safety according to World Economic Forum.

5.5. Site Management and Supervision: Site management and supervision have an important role in the success and development of construction project, it involves managing projects, bridges, roads, and industrial facilities. Construction managers should supervise resources, including equipment, materials, workforce, and budget. They should set up coordination with workers, consultants/Engineers, contractors, subcontractors to tackle delays of projects.

\section{REFERENCES}

1. M. Sambasivan and Y. W. Soon, "Causes and effects of delays in Malaysian construction industry," Int. J. Proj. Manag., vol. 25, no. 5, pp. 517-526, 2007.

2. M. Ghuszak and A. Les̈niak, "Construction Delays in Clients Opinion - Multivariate Statistical Analysis," Procedia Eng., vol. 123, pp. 182-189, 2015.

3. S. A. Assaf and S. Al-hejji, "PROJECT Causes of delay in large construction projects," Int. J. Proj. Manag., vol. 24, pp. 349357, 2006.

4. H. Doloi, A. Sawhney, K. C. Iyer, and S. Rentala, “Analysing factors affecting delays in Indian construction projects," Int. J. Proj. Manag., vol. 30, no. 4, pp. 479-489, 2012.

5. J. Bin Yang, C. C. Yang, and C. K. Kao, "Evaluating schedule delay causes for private participating public construction works under the Build-Operate-Transfer model," Int. J. Proj. Manag., vol. 28, no. 6, pp. 569-579, 2010.

6. R. F. Aziz, "Ranking of delay factors in construction projects after Egyptian revolution," Alexandria Eng. J., vol. 52, no. 3, pp. 387-406, 2013.

A. Senouci, A. Ismail, and N. Eldin, "Time Delay and Cost Overrun in Qatari Public Construction Projects," Procedia Eng., vol. 164, no. June, pp. 368-375, 2016.

7. G. Sweis, "Delays in construction projects: The case of Jordan," vol. 26, pp. 665-674, 2008.

8. S. Alsharif and A. Karatas, "Nuclear Power Plant Projects," Procedia Eng., vol. 145, no. 248, pp. 1486-1492, 2016.

9. J. A. Alsuliman, "Causes of delay in Saudi public construction projects," Alexandria Eng. J., vol. 58, no. 2, pp. 801-808, 2019.

10. D. Arditi, S. Nayak, and A. Damci, "ScienceDirect Effect of organizational culture on delay in construction," JPMA, vol. 35, no. 2, pp. 136-147, 2017.

11. C. Kaliba, M. Muya, and K. Mumba, "Cost escalation and schedule delays in road construction projects in Zambia," Int. J. Proj. Manag., vol. 27, no. 5, pp. 522-531, 2009.

12. C. Callegari, A. Szklo, and R. Schae, "Cost overruns and delays in energy megaprojects : How big is big enough ?," vol. 114, 
no. July 2017, pp. 211-220, 2018.

13. Alazemi, Mohammad Kh Th E., A. K. M. Mohiuddin, and Salloom A. Al-Juboori. "CONFLICT MANAGEMENT OF CONSTRUCTION PROJECTS-A CASE STUDY KUWAIT INTERNATIONAL AIRPORT CARGO CITY." International Journal of Mechanical Engineering (IJME) 8.3 (2019):4554.

14. Parikh, DHAVAL M., and G. J. Joshi. "Claim-cause relationship study of highway construction projects in India through factor analysis. "International Journal of Civil, Structural, Environmental and Infrastructure Engineering Research and Development (IJCSEIERD) 3.2 (2013): 4354.

15. Sharma, Savita, and Pradeep K. Goyal. "Cost overrun factors and project cost risk assessment in construction industry-a state of the art review." International Journal of Civil Engineering (IJCE) 3.3 (2014): 139154.

16. DHAWALE, AW, and ANSHUMAN C. PEMGIRIKAR. "COMPARATIVE STUDY OF COST AND DURATION RELATED TO NIGHT TIME AND DAY TIME CONSTRUCTION OF FLYOVER PROJECT. "International Journal of Civil Engineering (IJCE) 5.2 (2016): 18.

17. Taher, Enas Fathi, and R. K. Pandey. "Schedule Delay in Construction Project Using Time Impact Analysis." International Journal of Civil, Structural, Environmental and Infrastructure Engineering Research and Development (IJCSEIERD) 3.5 (2013): 5162.

18. PRAMONO, SURYO ADI. "THE CONFLICT OF INTEREST BETWEEN PEOPLE AND CORPORATION IN THE CONSTRUCTION PROJECT OF APARTMENT IN YOGYAKARTA INDONESIA A SOCIO-LEGAL PERSPECTIVE." International Journal of Environment, Ecology, Family and Urban Studies (IJEEFUS) 8.5 (2018):1522. 